\title{
Characterization of human anti-V3 monoclonal antibody 904 isolated from an Indian clade $C$ Human Immunodeficiency Virus type-1 (HIV-1) infected donor
}

\author{
Raiees Andrabi ${ }^{1,2}$, Muzamil Makhdoomi ${ }^{1}$, Kalpana Luthra ${ }^{1 *}$ \\ From Frontiers of Retrovirology: Complex retroviruses, retroelements and their hosts \\ Cambridge, UK. 16-18 September 2013
}

\section{Background}

Analysis of human monoclonal antibodies (mAbs) developed from HIV-1 infected donors have enormously contributed to the identification of neutralization sensitive epitopes on the HIV-1 envelope glycoprotein. We have isolated 3 anti-V3 mAbs 277, 903 and 904 by hybridoma technology from EBV transformed B cells of HIV-1 seropositive drug naive patients. The ELISA binding revealed a subtype-C and subtype-A specific binding of antibody 277 and 903 while 904 exhibited cross reactivity also with subtype-B V3. Epitope mapping of mAbs with overlapping V3 peptides showed exclusive binding to V3 crown. The antibodies displayed high and low neutralizing activity against $2 / 5$ tier 1 and $1 / 6$ tier 2 viruses respectively.

\section{Materials and methods}

To identify binding specificities of $\mathrm{mAb} 904$ within the V3 region specific to Indian clade $C$ viruses, we designed synthetic V3 mutant peptides (total of 23 peptides, 13 amino acid long), by amino acid substitutions and determined the binding reactivity by ELISA. Further, to assess the binding efficiency of mAb 904 to the native viruses of different clades, intact virion binding assays were performed.

\section{Results}

The binding of mAb 904 was substantially reduced (\% binding $=15.53$ ) by substituting with arginine-311 in place of glutamine (Q to R) (V3_3 peptide) in the crown region of the $\mathrm{V} 3 \mathrm{C}$. In addition to the above ( $\mathrm{Q}$ to $\mathrm{R}$ ), a second substitution of arginine-306 by aromatic amino

Department of Biochemistry, All India Institute of Medical Sciences, New Delhi, India

Full list of author information is available at the end of the article acid histidine ( $\mathrm{R}$ to $\mathrm{H}$ ) (V3_7 peptide), almost completely abrogated the binding ability of mAb 904 with the peptide (\% binding $=3.77$ ). This revealed that glutamine and arginine at positions 311 and 306 respectively within the V3 region of envelope gp120 are crucial amino acids required for binding of 904 . Lower binding potential of $\mathrm{mAb} 904$ with consensus V3B as compared to V3C (V3_1 peptide) is corroborated by the low binding to V3_8 mutant peptide (same amino acid sequence as that of con V3B) (\% binding $=3.55$ ). Another residue required for binding of $\mathrm{mAb} 904$ to $\mathrm{V} 3$ was observed to be phenylalanine (F) and when this was substituted by tryptophan (W) at position 313 of the V3 peptide (V3_16), there was substantial reduction $(\%$ binding $=15.27)$ in binding and when $\mathrm{F}$ to $\mathrm{W}$ change was accompanied with a second substitution of isoleucine (I) to methionine (M) at position 307 in the V3 region (V3_18), the binding of 904 to this double mutant peptide was further reduced by half (\% binding $=8.11$ ). A salient finding was that $\mathrm{mAb} 904$ retained the cross-reactive binding potential to $\mathrm{V} 3$ region of intact viruses of different clades, suggesting that V3 epitopes recognized by 904 are exposed on intact viruses.

\section{Conclusions}

Mapping revealed that $\mathrm{mAb} 904$ tolerates most subtype (C) specific changes and is a useful tool for identifying clade $\mathrm{C}$ epitopes for immunogen design.

\section{Authors' details}

${ }^{1}$ Department of Biochemistry, All India Institute of Medical Sciences, New Delhi, India. ${ }^{2}$ The Scripps Research Institute, La Jolla, California, USA. 
doi:10.1186/1742-4690-10-S1-P52

Cite this article as: Andrabi et al:: Characterization of human anti-V3 monoclonal antibody 904 isolated from an Indian clade C Human

Immunodeficiency Virus type-1 (HIV-1) infected donor. Retrovirology 2013 10(Suppl 1):P52.

Submit your next manuscript to BioMed Central and take full advantage of:

- Convenient online submission

- Thorough peer review

- No space constraints or color figure charges

- Immediate publication on acceptance

- Inclusion in PubMed, CAS, Scopus and Google Scholar

- Research which is freely available for redistribution

Submit your manuscript at www.biomedcentral.com/submit 